\title{
Incorporating Microsoft Certification into a State- Wide High School Completer Program to Support the Career and College Readiness of Students
}

\author{
Nicole Buzzetto-More \\ University of Maryland Eastern Shore, Princess Anne, MD, USA
}

\section{nabuzzetto-more@umes.edu}

\section{Introduction}

The workforce has changed dramatically as a result of technological advancements made in the past two decades. Career and Technology Education (CTE) programs offered at the secondary level are developed in response to an opportunity to add value to students' overall educational experiences. The goal of Career and Technology Education is to prepare students for postsecondary education and/or entry into a wide range of careers. Further, with middle skill occupations that require some post-secondary education or occupational certificate rapidly on the rise, a challenge has been put forth to increase the academic rigor of CTE programs so as to better prepare today's students for entry into the $21^{\text {st }}$ Century workforce.

Maryland, which is currently ranked the best education system in the United States for the fourth straight year by Education Week Magazine, has initiated an effort to increase the quality and academic integrity of CTE programs of study so as to better prepare students for career and college entry. Through this initiative is an effort to ensure that CTE students earn industry certification/licensure and transcripted college credits. This paper will focus on development of the Maryland State-Approved Business Administrative Services Pathway completer program, which has been designed so as to be aligned with the Microsoft Office Specialist Certification Program.

Keywords: Microsoft Certification, MOS, MSDE, Career and Technology Education, VET

\section{Literature Review}

In the past 30 years Harvard University estimates that virtually "all" of the job growth that has occurred in the United States has required some form of post-secondary education or professional licensure/ industry certification (Harvard University Graduate School of Education, 2011). In 2008 , the median earnings of workers with bachelor's degrees were $65 \%$ higher than those of individuals with a high school diploma and no additional professional certificate or licensure $(\$ 55,700$ vs. $\$ 33,800)$. Further, workers with associate's degrees earned $73 \%$ percent more than high school drop-outs $(\$ 42,000$ vs.

Material published as part of this publication, either on-line or in print, is copyrighted by the Informing Science Institute. Permission to make digital or paper copy of part or all of these works for personal or classroom use is granted without fee provided that the copies are not made or distributed for profit or commercial advantage AND that copies 1) bear this notice in full and 2) give the full citation on the first page. It is permissible to abstract these works so long as credit is given. To copy in all other cases or to republish or to post on a server or to redistribute to lists requires specific permission and payment of a fee. Contact Publisher@InformingScience.org to request redistribution permission.
$\$ 24,300)$ (College Board, 2010).

A study conducted by the Georgetown Center on Education and the Workforce (2008) projects that from 2008 to 2018 , about two-thirds of the job openings in the U.S. will require at least some postsecondary education and training. More specifically, approximately half of the jobs that will require post-secondary education will go to people with an as- 
sociate's degree or occupational certificate. Often referred to as middle skill occupations, they include such career paths as electrician, construction manager, dental hygienist, paralegal, health technologists, nurses, medical office specialist, office manager, administrative assistant, repair and installation, massage therapy, and police officer. Georgetown also reported that many of these jobs are high paying. In fact, according to their report $27 \%$ of people with post-secondary licenses or certificates credentials earn more than the average bachelor's degree recipient. Figure 4 demonstrates the changing composition of the American workforce from 1973 to 2007 courtesy of the Georgetown Center on Education and the Workforce (2008).

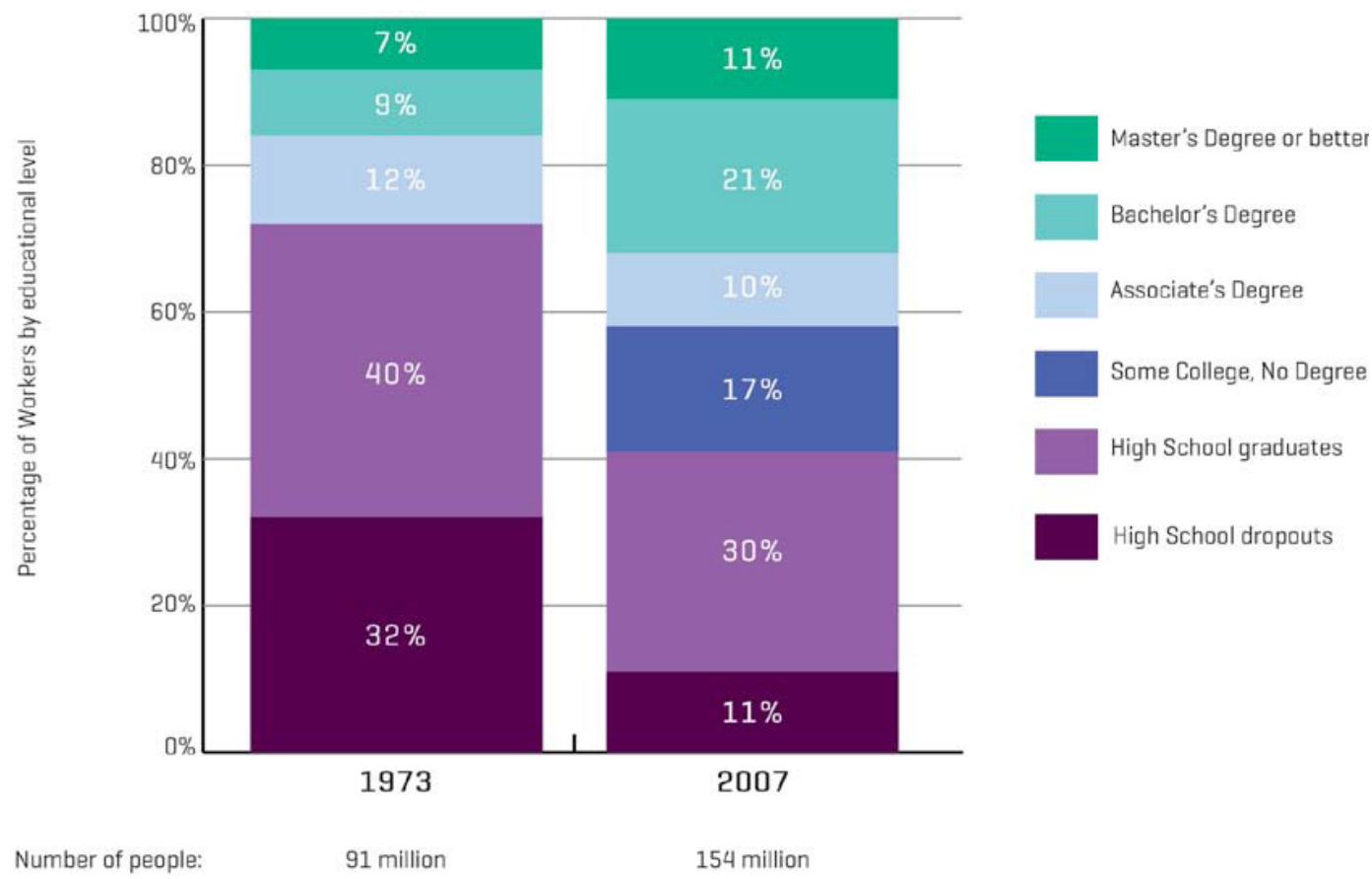

Figure 1: Changing Composition of the American Workforce

In the United States it is widely recognized that many young adults are not equipped with the skills to succeed as a contributing member of the $21^{\text {st }}$ Century Workforce. The Partnership for $21^{\text {st }}$ Century Skills, which includes such companies as Microsoft, Apple, Cisco and Pearson, has criticized the American educational system referring to it as obsolete and outmoded and has challenged educators to build such crucial skills as critical thinking, problem solving, creativity, oral and writing communications, and technological readiness into the learning process. Additionally, more than $80 \%$ of the manufacturers surveyed in a 2005 study reported that they are experiencing a shortage of qualified workers (Eisen, Jasinowski, \& Kleinert, 2005).

In 2009, President Barack Obama threw down the gauntlet and urged Americans to commit to educational achievement:

"And so tonight, I ask every American to commit to at least one year or more of higher education or career training. This can be community college or a four-year school, vocational training or an apprenticeship. But whatever the training may be, every American will need to get more than a high school diploma. And dropping out of high school is no longer an option. It's not just quitting on yourself, it's quitting on your country -- and this country needs and values the talents of every American." (Obama, 2009)

While higher education remains the ultimate attainment, vocational education should not be disregarded and relegated as archaic. Traditionally, in the United States little emphasis has been 
placed on vocational education and training (VET) and yet throughout the United Kingdom, Europe, and Australia vocational education plays a major role in contributing to the labor market as well as serving as a pathway to tertiary education (Harvard University Graduate School of Education, 2011). According to the United States Secretary of Education:

"For far too long, CTE (Career and Technical Education) has been the neglected stepchild of education reform. That neglect has to stop and second, the need to re-imagine and remake career and technical education is urgent. CTE has an enormous, if often overlooked impact on students, school systems, \& our ability to prosper as a nation.

The mission of CTE has to change. It can no longer be about earning a diploma and landing a job after high school. The goal of CTE 2.0 should be that students earn a postsecondary degree or an industry-recognized certification--and land a job that leads to a successful career... In effect, the President has suggested that every American earn a minimum of two pieces of paper - a high school diploma, and a degree or industry-recognized certification. In the years ahead, young adults are likely to need those two credentials to secure a good job. That will become the ticket to success and a positive future (Duncan, 2011)."

Career and Technology Education (CTE) programs are designed to prepare students for entry into post-secondary education and/or early professional careers. These careers require varying levels of education- from high school and postsecondary certificates, to apprenticeships, or two- and four-year college degrees.

Many CTE completers will go on to higher levels of education after high school and welldesigned CTE programs of study have been shown to help prepare students for post-secondary education (Grasmick, 2011). In fact, students who complete a rigorous academic core coupled with an academically challenging CTE program of study have test scores that equal or exceed college preparatory students. Additionally, they are more likely to pursue postsecondary education, have a higher grade point average in college, are less likely to drop out of college in the first year, and have an easier time finding internships and employment opportunities than non-CTE students (ACTE, 2011). In short, CTE programs have been cited for: preparing students to be career and college ready, helping students learn how to apply core academic skills to real world professional situations, building the employability soft skills of students such as communications and critical thinking, and providing students with job-specific technical skills (ACTE, 2011).

A study conducted by the National Research Center for Career and Technical Education (2007) found that CTE students scored significantly higher than their matched non-CTE counterparts on standardized tests, were more likely to complete dual-credit courses, and were more prepared than their matched non-CTE counterparts to experience an easy transition to college and careers. When surveyed, CTE students were significantly more likely to report that high school provided them with information on college programs and courses and more likely to report having a clear career goal and a plan to achieve their academic goals. Finally, CTE students have also been found to be significantly more likely to report that they developed problem-solving, project completion, research, math, college application, work-related, communication, time management and critical thinking skills during high school (National Research Center for Career and Technical Education, 2007).

Nationwide, more than 15 million high school students are enrolled in Career and Technical Education courses. Further, more than half of high school graduates who participate in CTE programs of study will go on to some form of postsecondary education (Duncan, 2011). According to the U.S. Department of Education's Office of Vocational and Adult Education (OVAE), almost all high school students take at least one CTE course, and one in four students take three or more courses in a single program area (ACTE, 2011). 


\section{Background}

In 2012, Maryland was ranked the nation's best education system for a fourth straight year by Education Week (a top national newspaper published in the United States that focuses on K-12 education published by the non-profit organization Editorial Projects in Education). The rankings were based on the State of the States analyzed by the Editorial Projects in Education Research Center report card which is based on survey data an analysis along more than 100 indicators that fall under 6 categories:

1. Chance for Success,

2. K-12 Achievement,

3. Standards, Assessments, \& Accountability

4. Teaching

5. School Finance, and

6. Transitions and Alignment

These six categories are separately graded and then averaged to form the basis of summative letter grades given to the nation overall and to the individual states. In 2012 Maryland, ranked at the top of the national list with a grade of $\mathrm{B}+$ plus. Maryland was followed by Massachusetts, New York, and Virginia, each of which earned a B. Overall, 41 states received grades ranging from Cminus to $\mathrm{C}+$ plus with the South Dakota ranking the lowest with a grade of $\mathrm{D}+$ plus. Finally, the United States K-12 educational system in its entirety received a grade of C, the same as the previous year (Editorial Projects in Education Research Center, 2012). Figure 2 presents the Maryland report card and Figure 3 depicts the overall grades and scores as well as and the individual states by rank courtesy of the Editorial Projects in Education Research Center and Education Week (2012).

\section{Maryland}

Chance for Success: $B+(87.8)$

Early foundations: A- $(90.8)$

School years: $B$ (84.2)

Adult outcomes: A- (91.1)

K-12 Achievement: B (83.9)

Status: B (85.4)

Change: $B+(89.3)$

Equity: $C-(71.7)$

Standards, Assessments, \& Accountability: $\mathrm{B}+$ (88.3)

Standards: A (96.4)

Assessments: $C+(78.3)$

School accountability: A- (90.0)
Overall: $\mathbf{B}+(\mathbf{8 7 . 8 )}$

The Teaching Profession: B (83.7)

Accountability for quality: $C(76.5)$

Incentives \& allocation: B (84.6)

Building \& supporting capacity: A- $(90.0)$

School Finance: $B+(86.6)$

Equity: $B+(87.3)$

Spending: B (85.8)

Transitions \& Alignment: A (96.4)

Early-childhood education: A (100.0)

College readiness: A- $(90.0)$

Economy \& workforce: A (100.0)

Figure 2: Quality Counts 2012 Maryland Report Card 


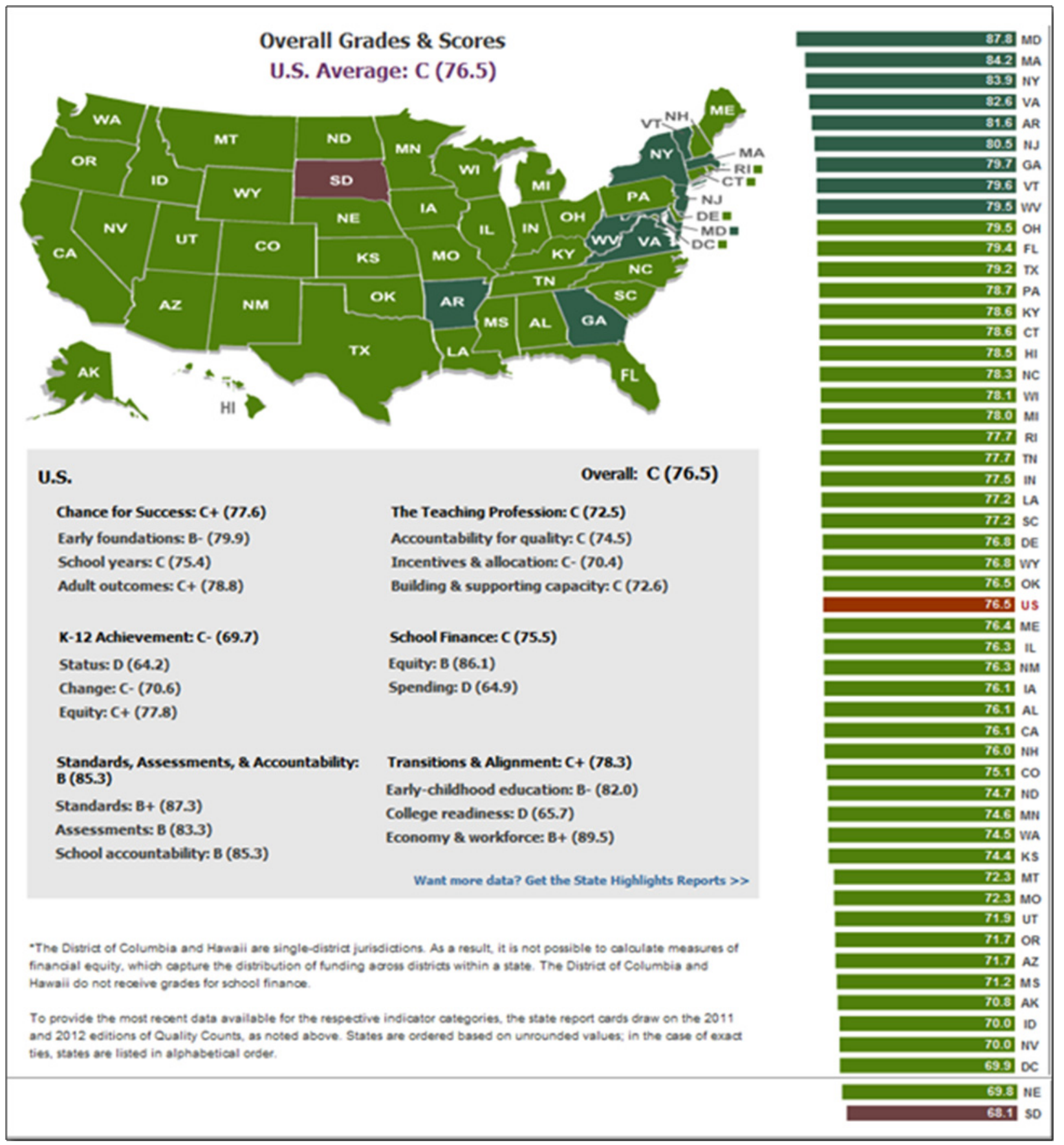

Figure 3: Quality Counts 2012 Overall Grades and Scores

The Washington Post also recognized Maryland for the highest percentage of rigorous high schools based on the Challenge Index, which exams the percentage of students taking advanced placement, international baccalaureate, or other nationally recognized academic or professional test (Washington Post, 2012).

During the 2009 school year, almost 108,000 high school students in Maryland enrolled in Career and Technology Education (CTE) courses, and 20\% of the Class of 2009 completed a StateApproved CTE Program of Study (MSDE, 2011). CTE programs in Maryland fall under the Divi- 
sion of Career and College Readiness. A major goal of this division is to enhance the Maryland Completer Programs so that they increase in rigor as well as lead to industry certification and the earning of credits. This is further influenced by Federal mandates issued by the O'Bama administration as well as through the Carl D. Perkins Vocational and Technical Education Act which Provides funds for secondary and post-secondary vocational and technical programs.

With middle-skill jobs making up the largest part of Maryland's labor market, Governor Martin O'Malley's administration introduced Skills2Compete Maryland (S2C) with the goal "for Marylanders to gain the skills and credentials they need to get good jobs with family supporting wages (Skills2Compete Dot Com, 2011)." Figure 4 depicts the projected job openings in Maryland by skill level between 2008 and 2018 and is provided courtesy of the Maryland Department of Labor, Licensing, and Regulation.

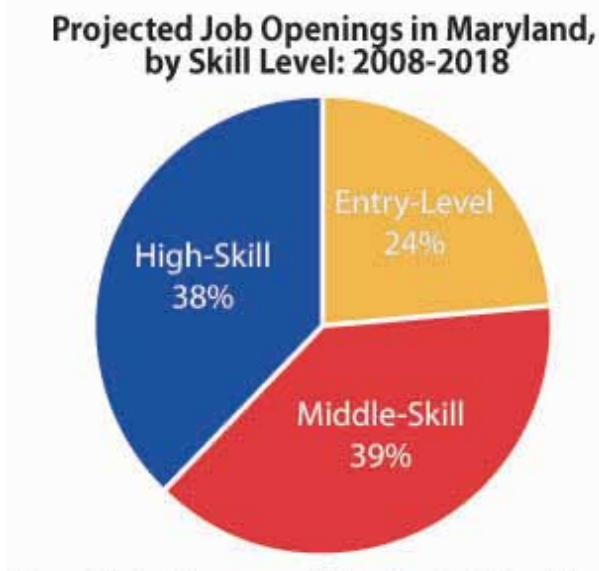

Source: Maryland Department of Labor, Licensing \& Regulation

Figure 4: Maryland Job Openings

According to the former Maryland State Superintendent of Schools, Nancy S. Grasmick: "Maryland takes seriously our responsibility to students, and has been working with our school systems to prepare our graduates for college and the workforce... We know our students must be able to compete with those from across the globe, and we must prepare them for that challenge (2011, p. 1)."

In Maryland, CTE programs of study are divided into 10 career clusters:

- Arts, Media and Communication

- Business, Management and Finance

- Consumer Services, Hospitality and Tourism

- Construction and Development

- Environmental, Agricultural and Natural Resource Systems

- Health and Biosciences

- Human Resource Services

- Information Technology

- Manufacturing, Engineering and Technology

- Transportation Technologies

Under each career cluster is several programs. The Maryland Business, Management and Finance (BMF) cluster focuses on five programs of study. The BMF programs are the most popular of the 10 CTE cluster programs in Maryland and include:

- Accounting and Finance,

- Marketing, 
- Business Administration and Management,

- National Academy of Finance, and

- Business Administrative Services.

Students in the BMF career cluster may elect to complete more than one pathway. Additionally, students may compliment their BMF program of study with internships, dual enrollment with an institution of higher education, and/or advanced placement courses

The popularity of the BMF programs coincides with the overall popularity of business as a major in the United States where it is consistently found to be the most popular college major in the nation (Princeton Review, 2010) for both men and women (United States Department of Education, 2010). Further, in terms of persistence to graduation and number of degrees awarded, business also holds the top spot representing nearly $25 \%$ of all degrees awarded annually (Goudreau, 2010). Students who complete high school business programs are found to be better prepared for academic success in college business programs (Sweitzer, 2011).

Each program in the Maryland BMF career cluster includes rigorous academics, broad cluster knowledge, and technical skills related to the specific program of study. Each course in a particular program of study is developed with postsecondary educators and professional partners. Skills for Success and other workforce requirements are integrated throughout the coursework, and include: workplace readiness, computer applications, written and oral communication skills, and math skills. Industry certifications are incorporated where appropriate and opportunities are sought for students to earn transcripted college credit through articulation agreements with State institutions of higher education. The goal of the BMF programs is to insure that each and every program of study graduates students with the skills and knowledge necessary to pursue postsecondary education and/or entry-level professional positions.

A current initiative exists in the State of Maryland to increase the rigor of CTE programs of study so as to better prepare students for careers and college as well as to help provide students with industry certification and transcripted college credits. This paper will focus on developments on the Business Administrative Services Pathway, (the first of the BMF pathways to be redesigned) which has been redesigned so as to align with the Microsoft Certification and $\mathrm{IC}^{3}$ exams.

\section{Business Administrative Services Pathway Re-Design}

The Maryland State Department of Education (MSDE) has committed itself to improving the Maryland High School Business, Management, and Finance Completer Programs to lead to industry certification and the earning of college credits. Incorporating certification and/or national standardized examinations into the programs of study is designed to increase the career and college readiness of students across the State of Maryland, enable students to earn college credit and valuable industry recognized professional certification, insure program validity and effectiveness, and measure and improve student achievement.

The first BMF cluster program to be addressed as part of this initiative was Business Administrative Services, which was upgraded to incorporate the Microsoft Office Specialist Certification program. The Business Administrative Services program focuses on building the day to day office operations, communications, and computer applications skills of program completers. It is not to be confused with programs included within the Maryland State Department of Education Information Technology career cluster, which has adopted Cisco Certification. Business Administrative Services as a field of study has a long history. In decades past it would have focused on such skills as typing, dictation, short-hand, preparation of correspondence, and general office work. Today, these skills have evolved and the Maryland Business Administrative Services Pathway provides students with knowledge of how to effectively utilize technology in the analysis, and communication of ideas; the completion of day to day office tasks; and the management, 
organization, and examination of information for strategic business decision making. Students are expected to think analytically; improve written and oral communication skills; enhance listening and questioning skills; apply accounting, marketing, and management principles through realworld projects; broaden their awareness of career options; practice decision making and problem solving; learn the importance of communication skills in professional business practice; develop team work and project management skills; prepare and deliver professional presentations; and utilize data to engender decision making (Maryland BMF Program Affiliate, 2011). While some program completers will seek entry level office positions, most will enter higher education where they will study management, marketing, accounting or another aspect of business.

The Microsoft Office Specialist (MOS) certification exam program was selected by a Governor's appointed State task force charged with selecting appropriate assessments to serve as summative assessments in all Maryland Career and Technical Education programs of study in 2008. For the remaining, BMF programs the College Level Examination Program (CLEP) series was selected. The Microsoft Office Specialist (MOS) was selected because it represents a globally recognized credential and a validated assessment measure. The MOS examinations assess a test-takers ability to apply their knowledge of key Microsoft Applications in a simulated in-application environment. Since most computer applications courses found in American colleges and universities focus on the Microsoft Office Suite, many institutions of higher education recognize MOS Certification granting college credit to students who have earned MOS credentials. Further, it is important to note that open-source office application software programs are not recognized or taught by the University System or K-12 educational system in Maryland.

Developed and delivered by Certiport, the MOS program is the only Microsoft Office certification endorsed by the Microsoft Company. Each year, Certiport delivers nearly 2 million certifications to students, academics, and professionals around the world through a global network of Authorized Testing Centers. These Testing Centers are licensed and categorized as servicing the Academic, Corporate, or Workforce Development Markets.

The Microsoft Office Specialist 2010 examination series includes three tiers of certification levels. They first tier provides core credentials in the major Microsoft Office application software (MS Word, MS Excel, MS PowerPoint, MS Outlook, and MS Access); the second tier includes Expert level exams available for MS Word and MS Excel; and the Master credentialing for advanced users requires passage of the MS Word Expert, MS Excel Expert and MS PowerPoint, and either MS Outlook or MS Access exams.

All courses within the pathway have been redesigned as part of this project as well as have the requirements for pathway completion. The curriculum design process started in the spring of 2010 with a State-wide curriculum and resource review, the distribution and analysis of a survey of Maryland teachers, focus groups, and a review of curricula in other parts of the United States. Concurrently, the Microsoft Office Certification examinations and the $\mathrm{IC}^{3}$ standards for digital literacy were carefully scrutinized and necessary skills and abilities were identified. While no prior State-wide approved curriculum existed at that time for the Business Administrative Services pathway, identified skills and abilities were compared against various existing local curricula found in the State and in all instances significant shortages were discovered. Further, a broad net was cast and no curriculum was found either in Maryland or across the United States at the high school level that had the breadth and depth of coverage, integration of core business concepts, and alignment with the MOS certification program that was desired.

The curriculum was designed in 2011 by the Maryland BMF (Business, Management, and Finance) Program Affiliate in collaboration with the Maryland State Department of Education BMF Cluster staffers. The Maryland BMF Program Affiliate was formed in 2010 and represents a partnership between the Maryland State Department of Education (MSDE) Division of Career and 
College Readiness and the University of Maryland Eastern Shore. In a collaborative effort, the Maryland BMF Program Affiliate works with the MSDE to provide leadership; professional development opportunities for teachers; curriculum and technical development services; the expertise need to insure program alignment with evolving industry standards and higher education expectations; and assistance with articulation agreements in order to ensure excellence across the BMF discipline

Learning objectives were developed for the Business Administrative Services pathway and specific skills identified. The objectives were presented at various meetings held across the State as well as posted online for commentary in the fall of 2010 . Once the objectives were finalized, they were expanded with detailed student performance indicators that took into account the careful scaffolding of skills and were designed to be appropriate for the intellectual development of the learners. The performance indicators were also presented to various constituent groups at meetings held across the State in the winter of 2010/2011. Both the learning objectives and the performance indicators were developed using the language found in Bloom's Taxonomy of Educational Objectives. Figure 5 represents an adapted version of Bloom's Taxonomy that was utilized for the development of BMF curricula as part of this project (MSDE, 2012).

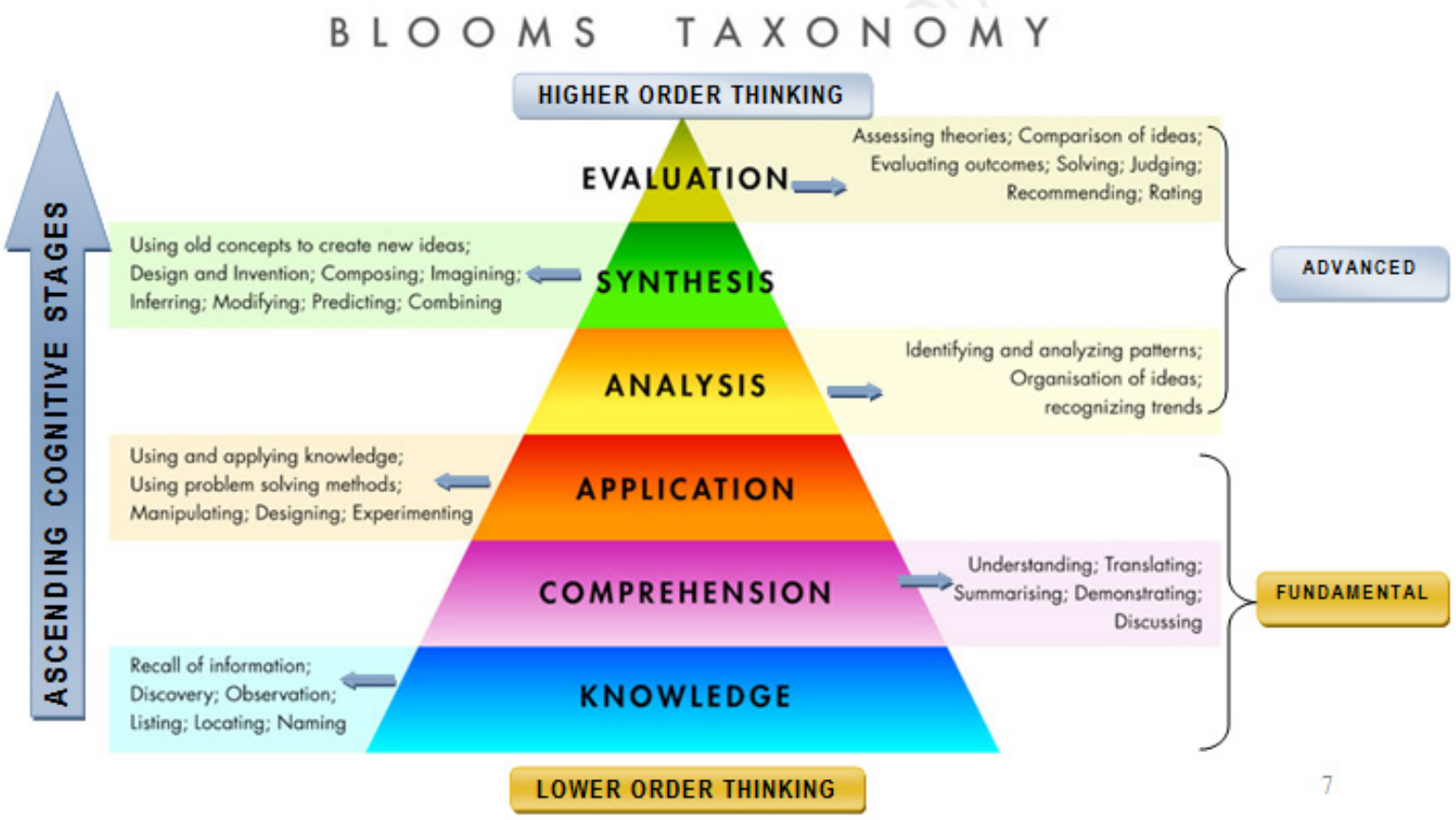

Figure 5: Bloom's Taxonomy of Educational Objectives

With the performance indicators in mind, the content was then divided to meaningful chunks, organized and sequenced, and placed into teachable units of study. Suggested projects and assessments were also added. Additionally, in order to cover the transition to the then recently released Microsoft Office version 2010, the curriculum adjustments were made to accommodate both the 2007 and 2010 versions of Microsoft Office. All new features inherent in Microsoft Office 2010 were highlighted and appropriately addressed within individual units.

Curriculum drafts were presented at various State-wide meetings to stakeholders and feedback was elicited throughout the spring of 2011. Additionally, drafts were made available for review and commentary to county supervisors as well as teachers across the State through the Maryland BMF Program Affiliate website as well as through email in the late spring/early summer of 2011. Feedback was solicited and used to inform revisions. Following a number of revisions, the final 
product was approved by the BMF State Advisory Council and released by the Maryland State Department of Education in August of 2011 where it remains housed on the Maryland BMF Program Affiliate Website available at www.BusinessEducationMSDE.com . The fifteen stages involved in the Business Administrative Services curriculum development process are illustrated in Figure 6.

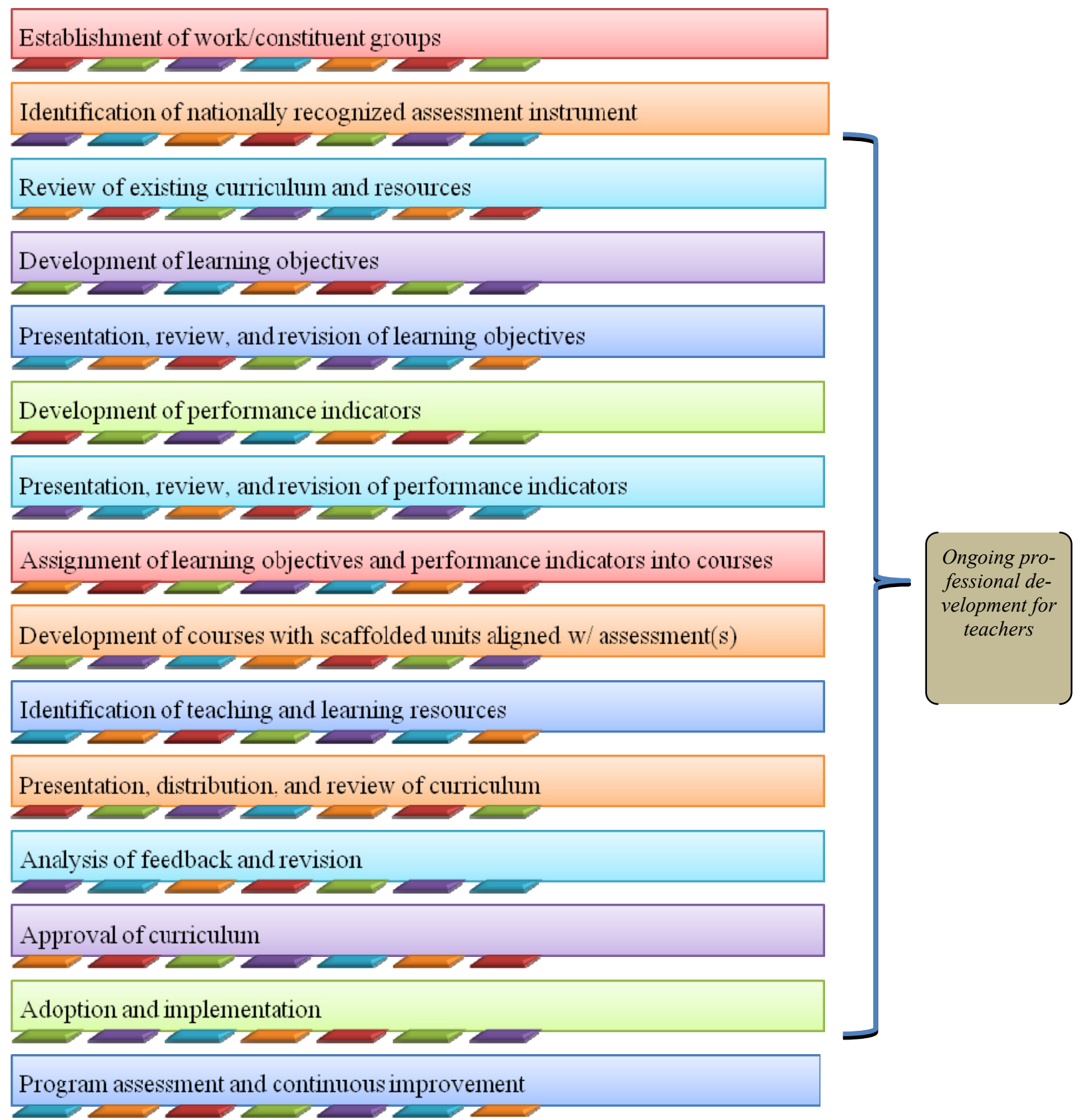

Figure 6: Curriculum Development Process

School districts that want to receive State funding dollars to support their Business Administrative Services program, are interested in developing articulation agreements with institutions of higher education, and/or which wanted to be recognized as having a State-approved program of study, were informed that they would be required to adopt the official State-approved curriculum. A four year period for adoption was identified. 


\section{Business Administrative Services Pathway Courses}

Students enrolled in the Business Administrative Services Pathway are required to take two foundation courses-Principles of Business Administration and Management; and Principles of Financial Accounting, both of which were also redesigned as part of this project. The first course, Principles of Business Administration and Management covers the role of business in a global society, American business as a dynamic process, forms of business ownership, management concepts, marketing, production and distribution, and accounting and finance. Students learn to analyze the functions of business through evaluating, planning, organizing, and controlling. Students are also expected to think analytically; improve written and oral communication skills; enhance listening and questioning skills; learn and practice the art of conversation; improve public speaking skills; broaden their awareness of career options; practice using teamwork to make decisions and solve problems; and learn why people skills, communications skills, and social networking skills can help them succeed in their careers (MSDE, 2011).

The Principles of Accounting and Finance course, which is the second required course in all Maryland Business Management and Finance (BMF) programs of study, provides students with the knowledge necessary to manage and maintain a company's financial resources. Students learn to apply generally accepted accounting principles (GAAP) to determine the value of assets, liabilities, and owner's equity as they apply to various forms of business ownership. Students prepare, interpret, and analyze financial statements using manual and computerized systems for service and merchandising businesses. Students also apply appropriate accounting principles to payroll and tax liabilities and examine the role of ethics and social responsibility in accounting decision making (MSDE, 2011).

Upon completion of the two foundation courses, students are required to complete Office Administration 1 and Office Administration 2. The Office Administration courses combine computer concepts, Microsoft Office 2010 computer applications, and applied business concepts. As an assessment, they require students to take Microsoft Office Specialist Certification Exams. The courses were designed to be performance based so as to include real world simulations, project based learning, and concept applications. Further, the Microsoft Office Certification examinations and the $\mathrm{IC}^{3}$ Certification were carefully scrutinized and the skills and abilities necessary for exam passage were identified. These identified skills and abilities were then incorporated into both the course learning objectives as well as integrated into the curriculum to ensure coverage. Figure 7 depicts the courses required in the Maryland BMF Pathways of Study. 


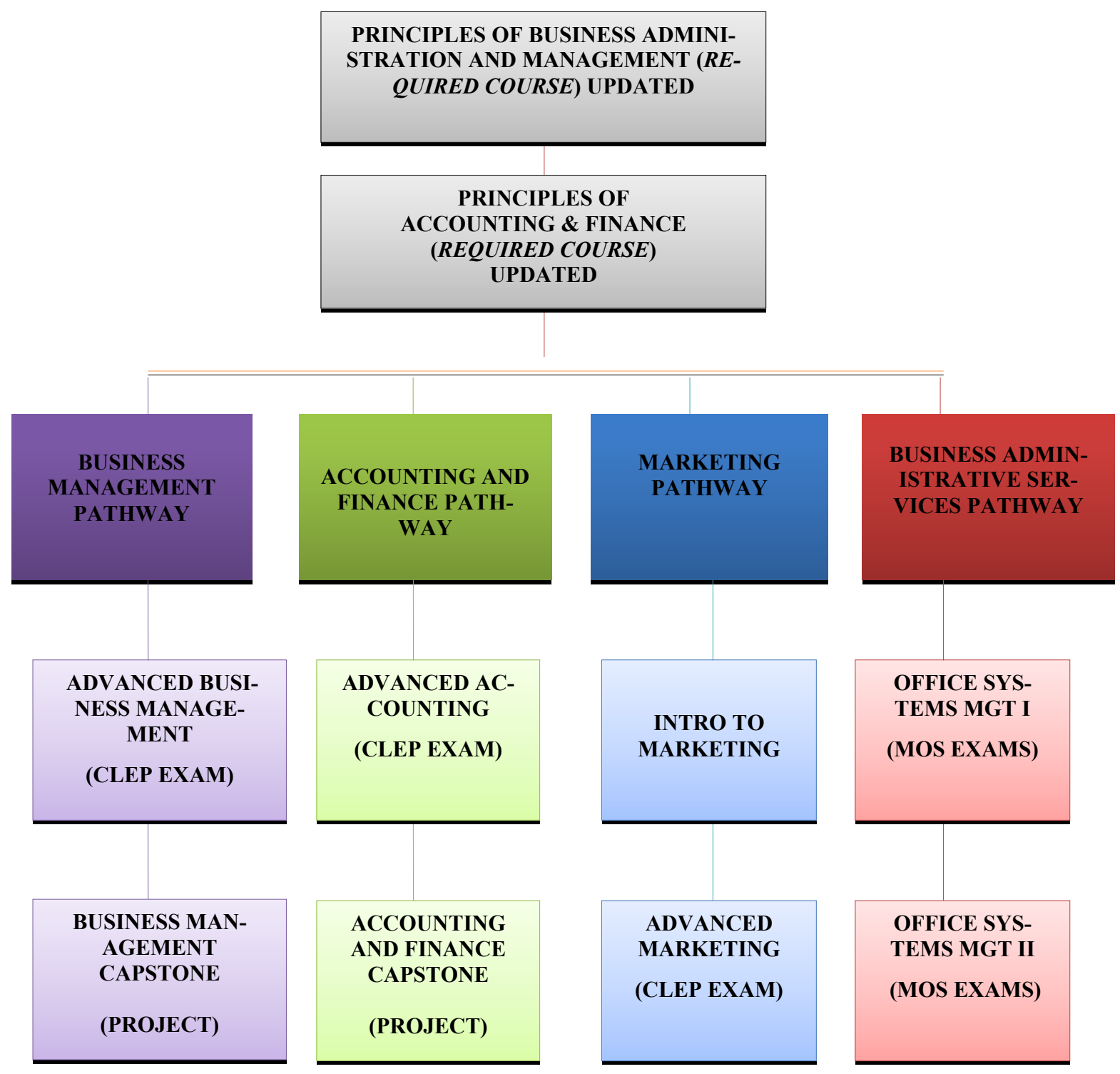

Figure 7: Course Sequence Maryland State Department of Education Approved Pathways of Study

\section{Office Systems Management 1}

In the Business Administrative Services Pathway, the Office Systems Management I course provides students with a study of basic business practices as well as knowledge of information systems and Microsoft Office applications. Students develop managerial and technical skills for business support operations through applied learning. Problem-solving skill development is incorporated throughout the course to meet the recommendations made through the Maryland Skills for Success. Competencies include: applying emerging technologies in order to complete appropriate office operations; using spreadsheet, desktop publishing and word processing software in order to create business documents and professional presentations; exhibiting appropriate interpersonal teamwork and leadership skills in order to succeed in the business world; demonstrating a knowledge of acceptable values and behaviors in order to become ethically responsible employees; and developing an appreciation of diversity in the workplace. The curriculum is comprised of twelve units with pacing and lesson planning left to the discretion of individual counties, schools, or teachers. The learning objectives for the program can be found below and the full curriculum including 
performance indicators and all teaching units is available on the Maryland BMF Program Affiliate website at www.BusinessEducationMSDE.com under the curriculum tab.

\section{Office Systems Management 1 Learning Objectives}

1. Student is able to explain major computing concepts.

2. Student is able to identify the major components of computing systems.

3. Student is able to conduct basic PC trouble shooting.

4. Student is able to explain networking fundamentals.

5. Student is able to identify how the internet and the World Wide Web each function.

6. Student is able to utilize the Web to locate information strategically and evaluate that information for usability and reliability.

7. Student is able to identify Internet threats and safety risks.

8. Student is able to perform basic file management in the MS Windows 7 Operating System.

9. Student is able to create and modify documents in MS Word.

10. Student is able to create and modify spreadsheets in MS Excel.

11. Student is able to create and modify a PowerPoint presentation and/or slide show with tables, imported and/or linked data, charts, graphics, images, multiple slide formats, handouts, themes and templates, and transitions and animation.

12. Student is able to utilize MS Outlook to send, receive, organize, and save Emails as well as create and modify contacts, schedule meetings, set reminders, and prepare and maintain a functioning calendar.

Schools are encouraged to integrate project based learning throughout the curriculum. The Microsoft Certification examinations for MS PowerPoint 2010 and MS Outlook 2010 are the recommended nationally recognized assessments. Additionally, the content for Office Systems Management 1 aligns with the Internet and Computing Core Certification (IC3) Certification assessment for digital literacy, which is based on Global Standard 3 an international standard for digital literacy developed and maintained by the Global Digital Literacy Council. IC3 marks a combination of three areas designated as constitution information literacy- Computing Fundamentals, Key Computer Applications, and Living Online. Computing Fundamentals Examination deals with hardware, software, operating systems, and peripherals. Key Applications Examination covers basic features inherent to most common computer applications for word processing, spreadsheets and presentations. Living Online covers internet safety, information literacy, cyber ethics, networking fundamentals, electronic communications, and professional uses of the internet and World Wide Web. Both the Microsoft Office Specialist and the $\mathrm{IC}^{3}$ Certification examinations are created and delivered by the Certiport Company.

\section{Office Systems Management 2}

In the Office Systems Management 2 course, students develop advanced skills using Microsoft's desktop software and acquire the Microsoft Office Specialist (MOS) credentials through passage of the MS Word and MS Excel certification exams. Students are required to think analytically, manipulate information, and use the computer as a productivity tool through integrated projects.

The curriculum has been divided into 3 modules. Module 1 covers the MOS Certification Process, MS PowerPoint and MS Access and is comprised of 2 Units. Module 2 focuses exclusively on MS Word, is aligned to the MOS Certification Examination for MS Word and is comprised of 11 units. Module 3 focuses exclusively on MS Excel, is aligned to the MOS Certification Examination for MS Excel, and is comprised of 11 units. While a total of 24 units have been identified, pacing and lesson planning is left to the discretion of individual counties, schools, or teachers. Further, as a BMF program of study, it is crucial 
that key business concepts are infused throughout this course and schools are encouraged to do this through hands-on course exercises and projects. The learning objectives for all three modules can be found below with module 3 offered in expanded form with identified performance indicators. The full curriculum including performance indicators and all teaching units is available on the Maryland BMF Program Affiliate website at www.BusinessEducationMSDE.com under the curriculum tab.

\section{Module 1 Learning Objectives}

1) Student is able to explain the MOS Certification process.

2) Student is able to create and prepare professional presentations in Microsoft PowerPoint.

3) Student is able to work with the Slide Master in Microsoft PowerPoint.

4) Student is able to identify the components of a database.

5) Student is able to create a simple database in Microsoft Access.

6) Student is able to perform a simple query in Microsoft Access.

\section{Module 2 Learning Objectives}

1) Student is able to demonstrate their knowledge by locating and using the Word options tool to customize Word and set defaults.

2) Student is able to apply their knowledge of Word and business writing into the preparation of mailings and the performance of mail merges.

3) Student is able to apply layout and formatting changes in Word

4) Student is able to illustrate and summarize ideas by using and modifying pictures, clip art, text boxes, Word Art, Smart Art, quick styles, and shapes.

5) Student is able to use Word to analyze, classify, compare, and relate information through tables, lists, graphics, and other objects.

6) Student is able to edit and prepare documents by using the review and reference tabs.

7) Student is able to organize content and structure with outlines.

8) Student is able to examine, inspect, and secure documents.

\section{Module 3 Learning Objectives with Performance Indicators}

1) Student is able to demonstrate basic formatting skills in the formatting of tabs, cells, columns, and worksheets.

- Use the Home Tab to arrange sheets and workbooks by hide/unhiding rows and columns, adding a new sheet, renaming a sheet, wrapping text, change orientation, centering and merging text across cells, altering text orientation, modifying tab color, customizing font and number formats, and modifying row/column width.

- Locate the features that will freeze panes, split worksheets, show/hide gridlines, arrange worksheets in the window, switch layouts, set print area, find and replace, paste only formulas or comments, zoom, and alter views .

2) Student is able to represent data in tables and charts

- Convert a spread sheet to a Table.

- Arrange and assemble concepts through the preparation of pivot tables and pivot charts.

3) Student is able to demonstrate the ability to create and use graphics and other visual elements in Excel.

- $\quad$ Use clip art, smart art, pictures, shapes, backgrounds, borders and shading, fill, and colors to organize and illustrate concepts.

- Select and customize themes. 
- Prepare smart art graphic organizers that interpret and/or represent ideas meaningfully.

4) Student is able to review formulas and data

- Review workbooks and validate formulas by removing duplicates, performing error checking, refreshing, and tracing precedents/dependents.

- Display formulas, track changes, and edit comments.

- Create rules and examine data integrity.

5) Student is able to protect, share, and manage workbooks.

- Manage, and share workbooks by protecting workbooks, designating ranges that can be edited by users, managing credentials.

6) Student is able to analyze data and synthesize concepts through the use of basic calculations.

- Analyze data and conduct basic computations by adding subtotals, and inserting formulas that calculate averages, modes, count, minimum, and maximum by using the Formula Tab.

- Prepare formulas that reference cells across sheets.

7) Student is able to analyze and present data through filters, sorts and conditional formatting.

- $\quad$ Present information by selecting a column and sort contents.

- Locate and turn on and off filters.

- $\quad$ Sort using multiple criteria.

- $\quad$ Prepare a custom auto-filter and use other advanced filtering.

- Differentiate data using conditional formatting

- Evaluate information by setting an above average condition.

8) Student is able to make predictions by creating scenarios.

- Use what-if analysis to synthesis concepts and make predictions through scenarios and goal seeking.

9) Student is able demonstrate the ability to name, use and edit ranges

- Name and set ranges, paste names and use names in formulas.

10) Student is able to appraise and assess data through the use of formulations.

- Insert a date or time formula.

- Use transpose to modify an array.

- Examine information by looking up and referencing an array of cells with HLOOKUP AND VLOOKUP.

- $\quad$ Differentiate, and examine information using simple conditional logic (IF, COUNTIF, THEN, AND, OR, SUMIF, SUMIFS, AERAGEIF, AVERAGEIFS, ETC)

- Create rules and examine data integrity.

\section{Curriculum Alignment}

A curriculum alignment was conducted that aligned the learning goals of each course with the respective unit(s) in which the goal is built. An example alignment chart is presented in Table 1. 
Table 1: MS Excel Curriculum Alignment

\begin{tabular}{|c|c|c|}
\hline & MS Excel Learning Objectives & $\begin{array}{l}\text { Applicable } \\
\text { Units }\end{array}$ \\
\hline 1 & $\begin{array}{l}\text { Demonstrate basic formatting skills in the formatting of tabs, cells, col- } \\
\text { umns, and worksheets. }\end{array}$ & Unit 1 \\
\hline 2 & Represent data in tables and charts & Units $2 \& 5$ \\
\hline 3 & Demonstrate the ability to create and use graphics in Excel. & Unit 3 \\
\hline 4 & Review formulas and data & Unit 6 \\
\hline 5 & Protect, share, and manage workbooks. & Unit 10 \\
\hline 6 & $\begin{array}{l}\text { Analyze data and synthesize concepts through the use of basic calculations } \\
\text { and formulas such as subtotals, data ranges, averages, modes, count, mini- } \\
\text { mum, and maximum. }\end{array}$ & Unit 4 \\
\hline 7 & $\begin{array}{l}\text { Analyze and present data through filters and sorts and conditional format- } \\
\text { ting. }\end{array}$ & Unit 4 \\
\hline 8 & Make predictions by creating scenarios. & Unit 7 \\
\hline 9 & Name, use and edit ranges & Unit 8 \\
\hline 10 & $\begin{array}{l}\text { Appraise and assess data through the use of intermediate formulations that } \\
\text { look up and reference data, modify text, calculate dates/time, or use simple } \\
\text { conditional logic (IF, THEN, AND, OR, SUMIF, AVERAGEIFS, ETC) }\end{array}$ & Unit 9 \\
\hline
\end{tabular}

\section{Implementation and Support}

School districts have been given a four year period for adoption. Funding dollars were, and continue to be, made available to districts to support the adoption of the new curriculum and include funding for books, software, and professional development training. Additionally, a mini-grant program was created to help school establish, or enhance, Certiport testing centers for the delivery of the Microsoft Office Specialist certification examinations.

To support the curriculum while it was still under development as well as following the release of the revised Business Administrative Services curriculum the following activities took place:

- week long Microsoft Office Certification teacher training workshops held on a State college campus during the summers;

- professional development days held at a museum in Baltimore opened to all BMF teachers and county supervisors in the State,

- informational sessions held at the Maryland Business Education Association (MBEA) conferences,

- development and distribution of handouts and other resources to teachers across the State;

- availability made to all teachers of the GMETRIX, Certiprep, and Measure Up examination and test preparation software,

- a discounted rate was negotiated for Certiport K-12 testing center site licenses,

- identification of textbooks and support systems and other resources, and

- a Website was developed to assist in the distribution of information as well as the curriculum review

Textbooks that did the best job of aligning to the new curriculum and which included project based learning and student support and assessment systems were identified. Attempts were made to work with publishers on the development of alignment charts. In the case of the first choice textbook and coordinating support system a detailed chart was produced that aligned learning goals and specific performance indicators with book chapters and pages, review assignments, and 
cases. Additionally, assessment and training tasks and simulation projects within the computerized student learning and assessment system were also included within the alignment.

A learning object repository to collect and make available relevant curriculum resources to teachers across the State is currently under development. The remaining BMF pathway completer programs in Accounting and Finance, Marketing, and Business Management are also being finalized and the State has begun efforts to create its first Computer Science completer program. Additionally, new articulation agreements with both community colleges and State institutions of higher education are being formed that will result in an increase in the number of students earning transcripted college credit as a result of program completion.

\section{Initial Results}

While this project remains in its early stages with classroom implementation still ongoing, some initial impact can be examined. Schools were notified about the decision to adopt the Microsoft Office Specialist certifications in 2008. Some districts elected to be early adopters of the MOS exams and in 2009, 786 MOS examinations were delivered. By 2010 that number had increased to 1,458 , with some schools using draft versions of the curriculum to help guide instruction. Finally, by the end of 2011 the number of certification exams delivered had reached 3,123. With most districts adopting all, or part, of the new curriculum, it is anticipated that the number of exams administered will also increase in 2012. Figure 8 depicts the change from 2009 to 2011.

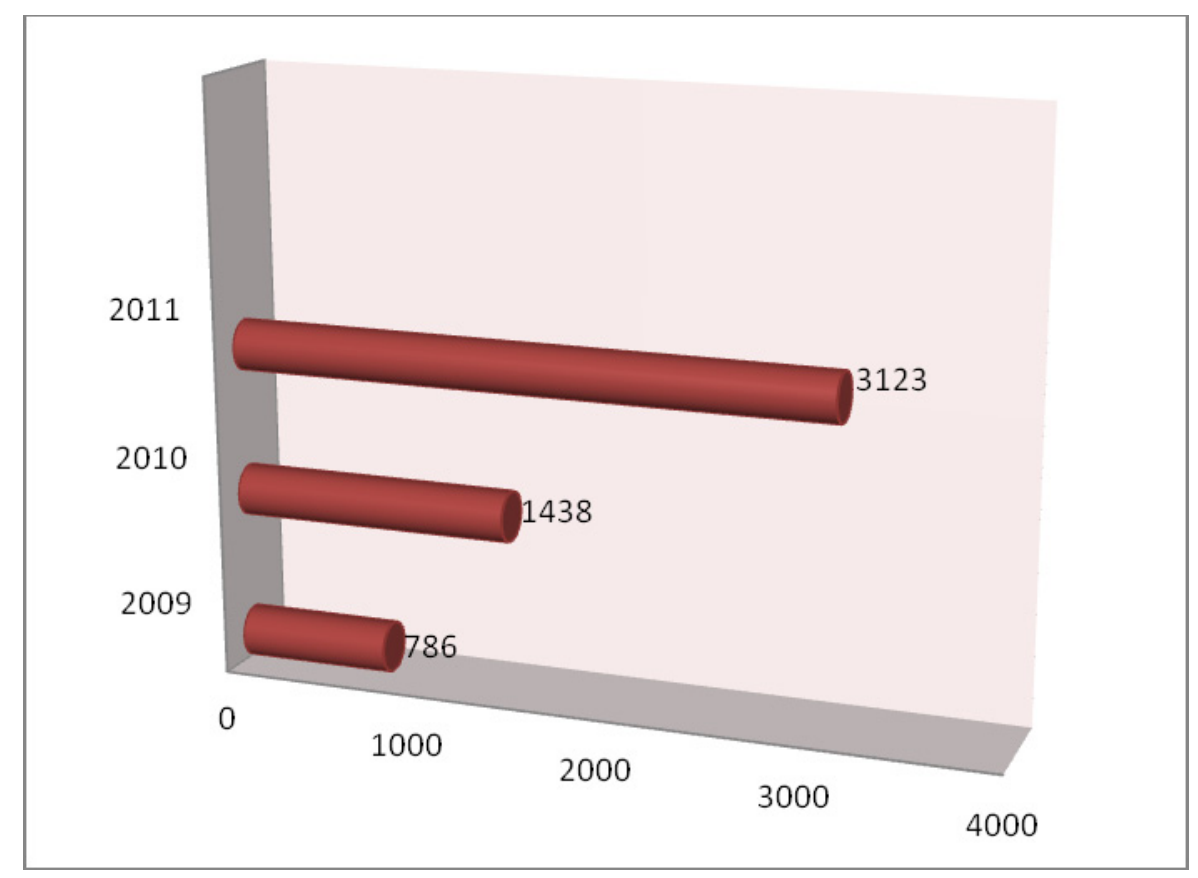

Figure 8: Maryland Microsoft Certification Examinations Delivered by Year 2009-2011

A discounted rate for school site licenses was negotiated in the summer of 2011. Due to the nature of the agreement the discounted rate cannot be reported in this paper; however, it has become advantageous for schools to purchase a site license over the individual purchasing of test vouchers. As of December 2011, 19 site licenses had been purchased. In 2012 a mini grant program was funded by the Maryland State Department of Education that made money available to schools to cover the expense of a Microsoft testing center and/or the purchase of a site license. As a result, it is anticipated that the number of school site licenses in Maryland will increase significantly throughout 2012. 
Student pass rates have increased over time. Initially, the pass rate for Maryland high school students on the MOS examination was around $30 \%$ by 2011 it has grown to $60 \%$, the same rate that the Certiport company reports is the average for all test-takers.

Some counties in Maryland have been particularly successful with the administration of the Microsoft Certification exams. For example, Queen Anne's County, a rural county with two high schools, that began implementing Microsoft Office Certification prior to the start of this project is currently certifying over 200 students each year, which accounts for about $20 \%$ of the student population (percentage also includes dual program completers as well as enrolled students who are not program completers) . Further, in the 2011 Microsoft Office Certification Program Competition, sponsored by Certiport and Microsoft, Queen Anne's County students took four of the top nine spots nationally. Certiport was so impressed with the accomplishments of the students in Queen Anne's County that they made a video to highlight the program. The video is available through YouTube at: http://youtu.be/iaOb4O2lpdY. With the new curriculum in place, availability of professional development for teachers, and introduction of support resources, the Maryland BMF Program Affiliate and the Maryland State Department of Education hope that counties across the State will be able to emulate the success of Queen Anne's County.

\section{Summary and Future Work}

Career and technology education has historically been neglected when it comes to educational reform; however, the value added by CTE programs in preparing students for career and college entry is now fully recognized. This paper presents the preliminary efforts of a project to introduce a State-approved program of study for high schools in Maryland that incorporates Microsoft Office Specialist Certification as a program assessment with the goal of increasing the career and college readiness of students. Data on student enrollment and completion has been maintained for some time and the collection process continues. Whether or not the introduction or the revised Business Administrative Services Pathway impacts student enrollment, completion, and college entry rates will be considered as the data becomes available. The number of Microsoft Office Specialist Certification exams taken by Maryland students will continue to be examined as will the exam pass fail rates. Additionally, a survey of business teachers and business education supervisors will be conducted. These findings will be presented in the second paper that will be produced as part of this project.

As we move forward, Maryland is currently finalizing a new Longitudinal Data System (MLDS). This initiative is one of the main components of the State's Race to the Top (RTTT) program, a competitive award program that rewards states for innovative initiatives to reform education, and involves the MSDE working to build a statewide technology infrastructure that links State education data with analytical and instructional tools to monitor and promote student achievement from Pre-K through college and early career entry (MSDE, 2011a). Through the Longitudinal Data System information about students who complete the revised Business Administrative Services Pathway will be collected and reviewed. Under consideration will be rates of college entry, freshmen year retention, college completion, and employment. This information will be presented in a future paper.

By sharing the efforts taking place as part of this project the author of this paper hopes to encourage CTE educators in other states or countries to consider similar forms of career and technical education curriculum development in order to increase the college and career readiness of learners. Currently, the marketing, accounting and finance, and business management curricula are in the review cycle. The curricula have been posted online as well as distributed at meetings and via email. An online survey has been posted on the program Website and feedback is being collected. The curricula are scheduled to be revised in the summer of 2012. 


\section{References}

Association for Career and Technical Education. (2009). Fact Sheet. Retrieved 11/22/11 from: www.acteonline.org/uploadedFiles/About_CTE/files/CTUFactSheet2.0-3.doc

College Board. (2010a). Education pays 2010. College Board Advocacy and Policy Center.

College Board. (2010b). The college completion agenda: 2010 progress report (pp. 10-14).

Duncan, A. (2011). The new CTE: Secretary Duncan's remarks on career and technical education. Retrieved 9/2/2011 from: http://www.ed.gov/news/speeches/new-cte-secretary-duncans-remarks-careerand-technical-education

Editorial Projects in Education Research Center. (2012, January 12). Quality counts 2012. Education Week.

Eisen, P., Jasinowski, J., \& Kleinert, R. (2005). 2005 skills gap report. National Association of Manufacturer's.

Georgetown's Center on Education and the Workforce. (2010). Help wanted: Projections of jobs and education requirements through 2018. Georgetown University.

Goudreau, J. (2010). Most popular college majors for women. Forbes. Com. Retrieved 3/10/2011 from http://www.forbes.com/2010/08/10/most-popular-college-degrees-for-women-forbes-womanleadership-education-business.html

Grasmick, N. (2011). Across the nation during the month of February, career and technology education programs are being celebrated during CTE Month. Maryland State Department of Education. Retrieved from: 2/16/2011 http://www.marylandpublicschools.org/NR/rdonlyres/F1D78DCC-1403-4029A4CB-BF6BB8106752/27453/oped_career_technology_03_2012.pdf

Harvard University Graduate School of Education. (2011). Pathways to prosperity: Meeting the challenges to prepare Americans for the $21^{\text {st }}$ Century. Harvard University.

Maryland BMF Program Affiliate. (2011). Welcome to the business, management and finance program affiliate. Retrieved 9/22/2011 from: http://www.businesseducationmsde.com/index.html

Maryland Department of Labor, Licensing and Regulation (2008). Projected job openings in Maryland 2008-2018. Retrieved 10/2/2011 from: http://www.skills.maryland.gov/benefits.shtml

Maryland State Department of Education. (2011a). Maryland's longitudinal data system. Maryland Classroom. 15(3). p1.

Maryland State Department of Education. (2011). Business administrative services pathway curriculum. MSDE.

National Research Center for Career and Technical Education. (2007). CTE pathway programs, academic performance, and the transition to college and career.

Obama, B. (2009). Remarks of President Barack Obama - As prepared for delivery address to joint session of Congress Tuesday, February 24th, 2009. White House Press Office.

Princeton Review. (2010). Top 10 college majors. Retrieved 1/20/2011 from http://www.princetonreview.com/college/top-ten-majors.aspx

Shatkin, L. (2008). Best jobs for the 21st Century. St Paul, MN, JIST Publishing.

Skills2Compete (2011). Skills2Compete benefits. Retrieved 11/13/2011 from: http://www.skills.maryland.gov/benefits.shtml

Sweitzer, K. (2011). High school preparation tips for aspiring business majors. Retrieved 3/17/2011 from http://businessmajors.about.com/od/undergradbusinessmajors/a/HighSchoolPrep.htm

U.S. Department of Education, National Center for Education Statistics. (2010). Digest of education statistics, 2009 (NCES 2010-013). 
Washington Post. (2012). High school challenge. Retrieved 1/20/2012 from:

http://apps.washingtonpost.com/highschoolchallenge

\section{Biography}

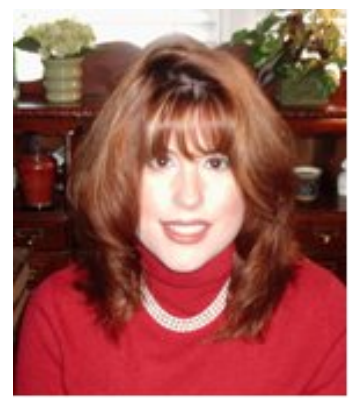

Dr. Nicole A. Buzzetto-More is an Associate Professor, program coordinator, and the Assurance of Learning Chair in the Department of Business at the University of Maryland Eastern Shore. She is also Director of the Maryland State Department of Education Program Affiliate for Business, Management, and Finance. She received doctorate and master's degrees in communications and instructional technology from Columbia University and earned a post doctorate in management from Tulane University. She also holds a masters from the College of New Rochelle and a bachelors from Marist College. She is a frequent presenter at conferences across the globe, is on the editorial board of several journals, has authored numerous publications, and has been recognized with awards from the American Distance Education Consortium, Global Digital Business Association, and the Informing Science Institute. Recently, she was named a Fellow of the Informing Science Institute. She published two books in 2007, Principles of Effective Online Teaching and Advanced Principles of Effective ELearning. In 2010 her third book The E-Portfolio Paradigm: Informing, Educating, Assessing, and Managing with E-Portfolios was published by the Informing Science Press. Nicole would like to acknowledge the contributions of the MSDE BMF team in particular Pat Mikos, Marianne Hollerbach, Bridgette Sloan, and William Nottage. The website for the Maryland BMF Program Affiliate is www.BusinessEducationMSDE.com. Dr Buzzetto-More's email address is nabuzzettomore@umes.edu 